University of Chicago Law School

Chicago Unbound

Public Law and Legal Theory Working Papers

Working Papers

2016

\title{
Why Tolerate Religion, Again? A Reply to Michael McConnell
}

Brian Leiter

Follow this and additional works at: https://chicagounbound.uchicago.edu/public_law_and_legal_theory

Part of the Law Commons

Chicago Unbound includes both works in progress and final versions of articles. Please be aware that a more recent version of this article may be available on Chicago Unbound, SSRN or elsewhere.

\section{Recommended Citation}

Brian Leiter, "Why Tolerate Religion, Again? A Reply to Michael McConnell," University of Chicago Public Law \& Legal Theory Paper Series, No. 580 (2016).

This Working Paper is brought to you for free and open access by the Working Papers at Chicago Unbound. It has been accepted for inclusion in Public Law and Legal Theory Working Papers by an authorized administrator of Chicago Unbound. For more information, please contact unbound@law.uchicago.edu. 


\section{CHICAGO}

Public LaW AND Legal TheORY WORKING PAPER NO. 580

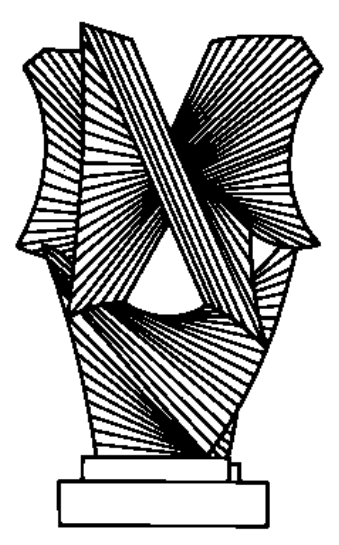

WHY TOLERATE RELIGION, AGAIN?

A REPLY TO MICHAEL MCCONNELL

Brian Leiter

THE LAW SCHOOL

THE UNIVERSITY OF CHICAGO

May 2016 


\title{
WHY TOLERATE RELIGION, AGAIN? A REPLY TO MICHAEL McCONNELL
}

\author{
Brian Leiter \\ bleiter@uchicago.edu \\ May 8, 2016
}

Like most philosophers and scholars used to laboring in relative obscurity, my experience of the very public reception of my 2013 book Why Tolerate Religion ${ }^{1}$ has been a (mostly) pleasant change of pace. Reviews appeared in the popular media in Britain, Italy, Denmark, Sweden and elsewhere; a French translation has already appeared; and an Italian translation is in the works. While "new atheist" types have generally been critical of me for not being intolerant of religion, some religious believers have, not surprisingly, taken a different view. The Family Research Council (a far right religious organization in the U.S., notoriously denominated a "hate group" by the Southern Poverty Law Center) condemned the book as, "[O]ne of the most troubling and intellectually discreditable books by a serious American scholar in some time." More soberly, First Things, a conservative Catholic magazine of ideas, worried that I had outlined "what may well become the theoretical consensus used to reinterpret the First Amendment." This struck me, but not them, as wild optimism. An Elder of the Mormon Church gave a major public address in which he discussed my argument, concurring with my defense of liberty of conscience, but disagreeing that religion should not be legally "special."

Now within academia, where religion looms less large, the reaction has been friendlier than in the public religious sphere. The political theorist John Gray, writing in Britain's New Statesman, called the book, "A model of clarity and rigour and at points strikingly original, this is a book that anyone who thinks seriously about religion, ethics and politics will benefit from

\footnotetext{
${ }^{1}$ (Princeton: Princeton University Press, 2013). Cited as WTR and by page number in the body of the text in what follows.
} 
reading." Religious liberty scholar Christopher Eisgruber, formerly of New York University Law School, and now President of Princeton University, said, "Every reader will learn something from this remarkable book, and, beginning now, every serious scholar of religious toleration will have to contend with Leiter's bold claims." And the Harvard Law Review opined that the book "exposes several tenuous assumptions underlying the predominant justifications for religious exemptions. At the same time, it provides a fresh and intuitive framework for analyzing conscience-based objections to facially neutral laws that should appeal to legal practitioners, jurists, and philosophers alike."

Even against this backdrop, I have to confess to being a bit surprised that the most distinguished and accomplished conservative scholar of law and religion in the United States, Michael McConnell, formerly a federal judge in Utah (appointed by President George W. Bush) and now a Professor at Stanford Law School, took the time to pen a lengthy review of my book in the Yale Law Journal. ${ }^{2}$ That Professor McConnell felt the need to devote forty pages to a 185-page book certainly suggested that something about the arguments had "touched a nerve". And although McConnell gets the majority of the arguments right, parts of the review do involve mistakes and misrepresentations that sometimes make it read a bit like a "hit job" on a book that, as First Things worried, might actually affect the consensus.

Professor McConnell makes clear at the start why he is worried (internal citations omitted):

Religious beliefs have always generated controversy. But religious freedom - the right of individuals and groups to form their own religious beliefs and to practice them to the

\footnotetext{
${ }^{2}$ Michael W. McConnell, "Why Protect Religious Freedom?” 123 Yale Law Journal 772 (2013). Cited hereafter by page number in the body of the text.
} 
extent consistent with the rights of others and with fundamental requirements of public order and the common good-has long been a bedrock value in the United States and other liberal nations. Religious freedom is one thing nearly all Americans, left and right, religious and secular, have been able to agree upon, perhaps because it protects all of us. Atheists are protected from imposition of prayer and Bible reading in state schools; churches are protected from interference with the hiring of ministers; religious minorities are protected from majoritarian legislation indifferent or hostile to their concerns. Progressive churches are protected when they oppose segregation or counsel draft resisters; traditionalist churches are protected when they oppose abortion or operate faithbased schools; nontraditional faith groups with unfamiliar worship practices are allowed to carry them out in peace. Because none of us can predict who will hold political power, all of us can sleep more soundly if we know that our religious freedom does not depend on election returns.

When the Supreme Court narrowed its interpretation of the Free Exercise Clause in 1990, in the so-called "Peyote Case," Employment Division v. Smith, Congress passed the corrective Religious Freedom Restoration Act (RFRA) by unanimous vote in the House and a margin of 97-3 in the Senate. Supporters included the ACLU, the National Association of Evangelicals, People for the American Way, the American Jewish Congress, the Christian Legal Society, and virtually every other religious and civil liberties group. Recently, however, this consensus seems to be weakening-largely from fallout over culture-war issues such as abortion and the legal recognition of same-sex 
relationships. Many activists on these issues see religion as antagonistic to their interests, and are responding in kind. A new whiff of intolerance is in the air.

University of Chicago law professor and legal philosopher Brian Leiter has entered the debate with his new book Why Tolerate Religion? His answer? Although we should not persecute religious believers, religion as such does not warrant any "special" legal solicitude such as that provided by the Religion Clauses of the First Amendment. "[T]here is no apparent moral reason why states should carve out special protections that encourage individuals to structure their lives around categorical demands that are insulated from the standards of evidence and reasoning we everywhere else expect to constitute constraints on judgment and action." Leiter argues, moreover, that it would be consistent with "principled toleration" for the secular state to affirmatively discriminate against religious believers in access to public spaces, such as by barring student Bible clubs from meeting on public school property, even when every other form of student organization is free to meet. So long as religious believers retain the right to express their own beliefs (including wearing religious symbols and clothing), the regime may advocate a "Vision of the Good" that is "irreligious" and may selectively deny religious believers and religious speakers equal access to public resources and opportunities. (772-773)

The final paragraph is a fair summary of my conclusions, though it omits the fact that I also think religious establishment is compatible with "principled toleration" (McConnell does note that later in the review). My book is silent on all the "culture war" issues, except the French culture war issue about banning the head scarf and Jewish skull caps in the public schools, which I argue is a case of impermissible intolerance. I was surprised, however, by McConnell's association of 
my argument with "intolerance," since it is a resounding defense of liberty of conscience (as the Elder of the Mormon Church correctly noted), including the liberty of religious conscience, but it denies that liberty of religious conscience is more important than other kinds.

Indeed, it is a curious feature of McConnell's discussion that he never offers a counterargument to the book's central thesis, other than noting that it entails some conclusions to which he is unsympathetic. If a demand for "equality of conscience" constitutes "intolerance," then I will have to plead guilty, but that seems to me a far better position, morally, than McConnell's endorsement of inequality. The closest McConnell comes to contesting my core thesis is to deny the plausibility (at 798-800) of one of my examples of the demands of non-religious conscience. Perhaps McConnell is right that the example is ill-chosen, though he does not really make that case. But only if McConnell believes that the non-religious never have conscientious obligations on a par with those of the religious would this matter. Does he really believe that? He is coy, so I am unsure, but I would hope he does not accept such an absurd thesis.

Among hostile readers, McConnell is admirable for how much he gets right about the actual argument of my book. And he makes two important, critical points that deserve further discussion by those interested in these issues.

First: I do in WTR assume, reasonably but without extended argument, that the most epistemically reliable standards of reason and evidence are those that have emerged from the natural and human sciences since the scientific revolution. McConnell is right to call attention to this assumption and the role it plays in parts of my argument (though not quite as many as he appears to believe) (786-789). His concrete challenges to the assumption are, alas, mostly sophomoric, including invoking the authority of Thomas Kuhn and Richard Rorty (apparently unaware of the vast literature post-Kuhn in the last fifty years, or that Rorty is not, 
shall we say, a philosophical "authority" in these matters), and invoking Alvin Plantinga, a leading philosopher of religion and apologist for the rationality of religious belief. He does not actually defend Plantinga's views on the merits, he just complains that I dismiss them without considering their merits. It is true that I do presuppose the philosophical consensus about the rationality of religious belief, and for a simple reason: others have written other books on this subject (e.g., John Mackie's The Miracle of Theism), and I can not do better than what they have already done. McConnell seems miffed by invocations of epistemic authority, even though his essay is awash in such moves--for example, when he objects that I can not say it is "unwarranted" to believe in God when "many persons, including thinkers of the first rank" (788) do so. Thinkers "of the first rank," of course, have always believed nonsense, hostage as they are to historical contingency and psychological need. But McConnell can not, unfortunately, have it both ways: if the opinions of "thinkers of the first rank" count, then the fact that the vast majority of philosophers of the first rank disagree with Plantinga also counts. McConnell is right to call attention to the fact that if the philosophical consensus is wrong about the epistemic status of some religious beliefs, that will affect some of my arguments (though not, e.g., the ones he singles out at p. 801). But the only relevant response would be on the merits of the epistemic arguments, about which McConnell is utterly silent.

Second: in the final chapter of the book, I argue that exemptions from neutral laws of general applicability should be available to all conscientious objectors, as long as they do not involve shifting burdens on to others. Although McConnell confuses the idea of "burdens" with the Millian Harm Principle $(803,805)$, he correctly objects that I do not say nearly enough about what constitutes acceptable and unacceptable burdens to help with the resolution of concrete cases, and offers some useful examples (803-807). He even notes that the "logic of 
[Leiter's] arguments may be more supportive of these claims for exemption than the more generalized rhetoric...would suggest" (807), though I would suggest the problem is that he read things into the "rhetoric" and ignored the actual "logic" of my arguments!

In the remainder of this reply, I want to correct five mistakes about or misrepresentations of the argument, and then comment on three misunderstandings or confusions (readers of my book will have to decide whether I am culpable for the latter--some reviewers have had related confusions, but many others have not). Most of the mistakes are minor (though some revealing), while the misunderstandings are perhaps more significant. I conclude with a brief comment on a "cheap shot" that ill-befits a scholar of McConnell's stature.

One very general, prelminary comment: McConnell, unsurprisingly given his expertise, mostly concentrates on the U.S. First Amendment, but my book is not about American constitutional law, and First Amendment cases figure only as an occasional example, far outnumbered by religious liberty cases from France, Italy, Germany, Canada, and elsewhere. I am interested in whether there is a moral justification for giving religion special legal solicitude, as all the Western democracies do; it is clear from my book that I think American First Amendment jurisprudence is in many respects--from "hate speech" to free exercise--morally indefensible. When McConnell chastises me for ignoring the history of the First Amendment, notes differences between my view and the justifications offered in Employment Division v. Smith (797-799), or notes that I disagree with the outcome in Smith given the facts (803), he is having a dialogue with himself, not my book. I will not belabor these distractions in what follows. 


\section{Five mistakes or misrepresentations:}

1. At p. 775, McConnell claims that I "examine several prominent justifications for toleration offered by John Rawls, John Stuart Mill, and Frederick Schauer," even though I am explicit in Chapter 1 that Schauer's argument is not an argument for toleration, whereas Rawls's and Mill's are. McConnell then repeats that mistake at pp. 782, 795, and 796. Chapter 1 of my book distinguishes arguments for "principled toleration"--namely, putting up with beliefs and practices of which we disapprove because it is morally right to do so--from non-moral arguments for putting up with beliefs and practices of which we disapprove, basically arguments of the form that being intolerant is too costly (Hobbes), ineffective (Locke), or can not be carried out correctly, due to governmental incompetence (here Schauer's famous argument in the free speech context is the example). How McConnell conflated these is mystifying. His complaint (p. 796) that I did not spend more time on Schauer's argument reveals that he did not understand the difference between arguments for principled toleration (like Rawls' and Mill's) and the others. When he says, in the same vein, that my "entire book is about what this infallible 'we' should do about religion" (796), I was simply astonished that he had confused the question what was morally justifiable with the question will institutions do what is morally right. Both are good questions, but they can be distinguished, and they are very clearly distinguished in my book. These are silly mistakes to have made, but they are minor.

2. At p. 782, McConnell complains that the book "provides no definition of 'conscience,'" but this is false. (There is even an index entry on "conscience, defined" leading readers to the place: "While an experience of categoricity is central to anything that would count as claim of conscience, a suitable account of conscience will presumably require a second dimension--namely, that the agent identify with or endorse the categorical command" [WTR, 
148-149 n. 17].) He continues his criticism of my idea of conscience at p. 785 , but then quotes me saying that it is "unlikely any legal system will embrace this capacious approach to liberty of conscience" [WTR, 39-40], as though I were agreeing with him about the vagaries of conscience, when the point has nothing to do with that: the point is that no legal system will agree to a scheme of universal exemptions for all claims of conscience. This is also minor.

3. My account of religion in Chapter 2 is conjunctive: religious claims of conscience are distinguished by the conjunction of three characteristics: (1) "there are at least some beliefs central to the religion that...issue in categorical demands on action" (WTR, 34); (2) "there are at least some beliefs central to the religion that...are insulated from ordinary standards of evidence and rational justification, the ones we employ in both common sense and in science" (WTR, 34); and (3) "there are some beliefs...that render intelligible and tolerable the basic existential facts about human life, such as suffering and death" (WTR, 52). First, McConnell says, incorrectly, that my account of religion does not include (3) (783). Second, McConnell notes that I recognize that neither (1) nor (2) is distinctive of religion, but then thinks this is an objection to my view, failing to recognize (remarkably) that my thesis is that the conjunction of (1), (2) and (3) picks out what is distinctive of religion. Surprisingly, McConnell offers no counter-examples to my characterization of religion. (He notes [at 784], as I do as well [cf. my discussion of Durkheim at WTR, 27-30], that religions typically involve practices and communities, but this is morally irrelevant, absent a showing--McConnell does not even pretend to offer one--that those features are such as to demand principled toleration, and to demand it of religion uniquely.)

4. I consider some of the practical problems that would confront a scheme of "universal exemptions" for claims of conscience, considering some ways of resolving them. McConnell completely misstates my conclusion as being that "it is permissible, after all, to single out 
religious claims and those nonreligious claims that 'mimic' religious claims, and to give them special solicitude" (802). But that is manifestly not the conclusion (see WTR 98-100). That some (but not all) of the practical obstacles to a universal scheme of exemptions could be overcome is not an argument for religious conscience being special and, moreover, it is irrelevant to my main objections to exemptions, namely, that such exemptions often defeat the pursuit of the general welfare (the "Rousseauian objection" as I call it in the book).

5. At p. 808, after noting my discussion of why "principled toleration" could be compatible with the establisment of Catholicism, he declares, falsely, that "[w]hat [Leiter] defends is the establishment of securalism." This is astonishing, and there is, of course, no footnote accompanying this false assertion. Chapter 5 argues that every state establishes a "Vision of the Good," and that such establishment, whether religious or irreligious, can, under the right circumstances be compatible with the demands of principled toleration. (McConnell actually agrees with that at the top of p. 808!) At this point, the mistakes have now descended to the level of a Bill O'Reilly or Sean Hannity hatchet job. Fortunately, this comes towards the very end of the review, and while it reflects poorly on McConnell's motives, it does not mar most of the review.

\section{Three misunderstandings and confusions}

1. Why should we protect the free exercise of religion (or other conscientious commitments)? My thesis is that such protections depend upon the moral ideal of "principled toleration" (above). McConnell objects that the First Amendment "does not deem religious belief 'wrong, mistaken, or undesirable'" (779). Well, of course, I did not say that it did. The point is, rather, that when religious believers seek exemptions from laws that proscribe conduct, they are asking for legal toleration of conduct of which the state has disapproved through its 
laws: this is clear in the example I use throughout the book, namely, prohibitions on weapons in the schools, which devout Sikhs (who must carry a Kirpan, a ceremonial dagger) have challenged, successfully, in many jurisdictions. McConnell, alas, extends the confusion into his brief reference to my Chapter 4 where I consider the possibility that a moral ideal of "respect," rather than toleration, is the foundation for liberty of conscience, including religious conscience (780). He notes, correctly, that I am interested in state toleration, but then is confused by the way in which I analyze the different senses of "respect" in Chapter 4, where I use interpersonal examples. This is just a standard method of philosophical analysis of concepts: one uses examples to elicit intuitions about how the concept applies. It may be that the interpersonal examples of "respect" do not map on to institutional ones, but McConnell does not even attempt to make that case.

2. At pp. 786-787, McConnell complains that my characterization of religion (see the discussion of 783-784, above)--in particular the point about insulation of some aspects of religioug belief from scientific standards of evidence and reasons--"smuggl[es] into the definition of religion a feature that makes religious belief seem unreasonable." There is no "smuggling": I am just trying to explain the sense in which all religions involve some beliefs that are supposed to be accepted on "faith." McConnell, in trying to explain this idea, ends up, surprisingly, by the next page (787), proposing as acceptable the idea that religion involves some beliefs "in which significant aspects are not based on science or common sense observations about the material world"--which is basically my definition! I think what has happened is that McConnell has confused his fair criticism about whether these standards are the only epistemically reliable ones (discussed at the start of this reply) with the attempt to define religious conscience. He seems to have no disagreement, judging from p. 787, with my 
definition of religious conscience. McConnell also spends time (on 787) arguing that "much religious thought is not 'insulated'" from ordinary standards of evidence and reason in the sciences. This is obviously true, and has no bearing on the thesis that every religion involves some beliefs that are so insulated (no one thinks all religious beliefs are so insulated).

3. In Chapter 5, I discuss the question whether religious establishment is compatible with the demands of principled toleration. I conclude that it can be, under certain circumstances, which I discuss at some length. I also note at WTR 129-130 that establishment might offend against equality values. McConnell objects that I "say[] no more against" establishment than this (808). This then leads in to the hatchet job noted already (i.e., the false allegation that the book defends the establishment of secularism). I realize that lawyers often argue to win, and little else--this was a fatal flaw of so much of Dworkin's jurisprudential work. But philosophers are actually a bit different some of the time: sometimes we just want to figure out what is correct, what follows logically from our initial premises. In the final Chapter 5 of my book, I try to show that the moral demands of principled toleration are compatible with religious establishment. I also note that religious establishment may be incompatible with equality values (a point emphasized in Martha Nussbaum's work). I do not try to resolve the issue, I flag it for the thoughtful reader. The ideological reader might, understandably, be unhappy.

\section{The "Cheap Shot"}

Finally, I must comment on a cheap rhetorical shot that McConnell (quite

unnecessarily) takes, one that, unfortunately, reveals his review as more of a partisan brief than a scholarly evaluation of an argument. While discussing the utilitarian argument for liberty of conscience (not the Rawlsian argument, as McConnell incorrectly describes it at p. 790), I briefly note the possibility that "many, perhaps even most" people "make foolish choices about 
what to believe and how to live," with the result that they make themselves worse off, contrary to the utilitarian argument (WTR 18, discussed at p. 790 in McConnell's review). I do not pursue the issue. Remarkably, McConnell refers to these brief comments as "authoritarian musings," which calls to mind Glenn Beck's tirades against Cass Sunstein's skepticism, informed by empirical psychology, about our individual capacity for rational choice. Socrates, Plato, Hegel, and Marx, among others, worry about the possibility I reference; so, too, does Mill, who is rather clear that liberty only maximizes utlity if certain background conditions of education and maturity obtain. (Sarah Conly has recently argued that Mill is unduly optimistic, given what we learn from the kind of psychology Sunstein invokes: see her Against Autonomy: Justifying Coercive Paternalism [Cambridge U Press, 2013], favorably reviewed by Sunstein in The New York Review of Books, a review which, Conly tells me, was picked up by Beck and his followers, and led to weeks of threats against her because of what they perceived to be her "authoritarian musings.")

One might excuse this inapt phrase, except McConnell repeats the same theme at various places. (I won't review them all.) For example, he calls me the "Anti-Mill" (p. 794) and then accuses me of being "elitist and authoritarian" (794). (That McConnell descends to this level of rhetorical childishness reminds me more of cyberspace than a scholarly debate!) The actual philosophical puzzle (WTR 55-58 in my book) that prompts these epithets is the following. First, I point out that it would be quite wrong to think that a Millian argument for liberty of conscience could dismiss religious claims of conscience on the grounds that they do not lead to discovery of the truth. As I write: "it might seem to be precisely in the spirit of Millian epistemic libertarianism to think that alternative epistemic methods [i.e., alternative to those operatives in the sciences]...be permitted in the interests of discovering new truths" (56). 
I then point out a curious fact about Mill's position, namely, that he thinks there is no reason for such epistemic libertarianism in the case of mathematics, since (quoting Mill), "The peculiarity of the evidence of mathematical truths is that all the arguments is on one side." Against this, McConnell adduces a quote in which Mill mentioned "morals" and "religion" as topics on which different positions are possible (794-795). Obviously, I read On Liberty too and am aware of what Mill says. The philosophical question is whether Mill's own position hangs together coherently (Conly makes a similar point about other aspects of Mill's arguments--indeed, the philosophical literature on Mill is almost entirely about whether what he says squares with the reasons he offers!). As I observe,

Mill is a radical empiricist, and so denies that there is any a priori knowledge: even logical and mathematical truths are a posterioi, vindicated by inductive generalizations based on past experience. (WTR 57)

Since Mill's claim about the "peculiarity of mathematical truths" is based on an inductive generalization over empirical evidence, this raises a quite serious question about what other generalizations are warranted on Millian grounds. (My favorite example is: surely we have enough empirical evidence to know that in an argument about the moral value of Nazism, "all the arguments [are] on one side," i.e., not the Nazi one) Is there an inductive, empiricist case in favor of the epistemic reliability of "the standards of evidence and reasons that have been vindicated a posteriori since the scientific reovlution" (WTR 57)? That is the question I raise. McConnell never even mentions the puzzle of how Mill's empiricism is to be squared with his view about mathematical truth (I am guessing he just did not understand the issue), and about how that empircism might support my claim. Nor does he note that I do not even claim empircist vindication for the conjecture at p. 57, arguing instead that there are other reasons why 
the possible epistemic reliability of "religious" cognition would not matter anyway to the Millian argument (WTR 58). This argument may be wrong, but McConnell never notices it.

Even if these "cheap shots" detract from the review, I do not want to end on a negative note. That Professor McConnell devoted so much time and energy to critiquing my book--even though, as best I can tell, he never responded to my challenge about why religious liberty is more important than other kinds of liberty of conscience--suggests to me that, as First Things worried, I may be right. There are no doubt deficiencies in my book (including some McConnell correctly notes), but on the fundamental point--the indefensible inequality between religious and non-religious conscience that is the legal status quo in so many jurisdictions--it appears there may really be no serious argument on the other side! In any case, the proponents of this inequality, like McConnell, have yet to offer one. 